\title{
DISAIN LAYANAN KENDARAAN UMUM BERBASIS FUZZY-KANO QFD
}

\author{
Oleh : Prihono *)
}

\begin{abstract}
Abstrak
Layanan kendaraan umum semakin dituntut untuk bisa memuaskan konsumennya. Namun kualitas layanan yang diberikan oleh penyelenggara layanan kendaraan umum masih mengabaikan kebutuhan konsumennya. Hal ini dikarenakan layanan yang diberikan masih berasal dari persepsi penyelenggara layanan. Dengan kondisi ini, yang perlu diperhatikan adalah upayaupaya untuk meningkatkan kepuasan layanan yang ditujukan kepada penumpang dengan memperhatikan kebutuhan-kebutuhan konsumennya. Penelitian ini bertujuan untuk mengidentifikasi kebutuhan sistem layanan kendaraan umum dan merancang sistem layanan kendaraan umum.

Penelitian ini dimulai dengan mengidentifikasi Voice of Customer dengan menggunakan metode Kano, yaitu dengan memberikan pertanyaan functinal dan dysfunctional kepada responden. Selanjutnya digunakan metode fuzzy untuk mengurangi subyektivitas dari jawaban responden, yang selanjutnya diklasifikasikan masing-masing atribut ke dalam kategori Kano yaitu : kategori must be, one dimensional, attractive, dan indifferent. Untuk mendesain system layanan, maka digunakan metode Quality Function Develompment (QFD).

Analisa dengan Quality Function Development (QFD), didapat 11 (sebelas) kriteria kebutuhan layanan VoC (Voice of Customer) dan 26 (dua puluh enam) atribut respon teknis yang digunakan untuk mendesain sistem layanan. Perhitungan untuk VoC untuk bis penumpang umum, nilai tertinggi pada atribut ketersediaan tempat duduk dengan skor 9,64. Untuk itu, hal yang bisa diusahakan yaitu dengan menambahkan armada bus dan juga bisa menjadwalkan rute yang lebih banyak. Selain hal diatas, perlu adanya petugas keamanan serta informasi dan pengaduan konsumen, yang skornya 7,73 dan 7,66.
\end{abstract}

Keyword: kendaraan umum, model Kano, fuzzy, QFD.

\section{PENDAHULUAN}

Peningkatan kualitas merupakan salah satu strategi bisnis yang ditekankan pada pemenuhan keinginan konsumen. Di sisi lain, kinerja perusahaan dan kepuasan konsumen merupakan satu kesatuan yang sulit untuk dipisahkan. Kinerja berpengaruh langsung terhadap kepuasan konsumen. Oleh karena itu, suatu unit bisnis diharapkan dapat meningkatkan kinerjanya, dimulai dengan mengetahui sejauh mana tingkat kepuasan yang diperoleh konsumen.

Usaha untuk meningkatkan kualitas layanan perusahaan dalam rangka memenuhi kepuasan konsumen merupakan salah satu usaha yang sangat penting. Karena dalam banyak hal, konsumenlah yang membuat keputusan untuk apa layanan perusahaan tersebut untuk dikomsumsi dan seberapa mampu layanan perusahaan tersebut mencapai tujuan yang diharapkannya. Oleh karena itu diperlukan suatu cara atau model yang bisa menerjemahkan kebutuhan dan keinginan konsumen.

Kano merupakan metode yang bertujuan untuk mengkategorikan atributatribut dari produk maupun jasa berdasarkan seberapa baik produk atau jasa tersebut mampu memuaskan kebutuhan konsumen.
Model Kano menggolongkan 3 (tiga) tipe pemenuhan kepuasan konsumen yaitu Must$\mathrm{Be}$, One Dimensional, dan Attractive (Sauerwein at al, 1996). Kombinasi model Kano dengan metode lainnya juga sudah dilakukan. Hanoum at al (2009) telah menggabungkan dan membandingkan model Kano dengan IPA (Importance Performance Analysis). Dimana kasus yang diteliti adalah kualitas penyedia layanan kesehatan. IPA (Importance Performance Analysis) mampu menggolongkan dan memprioritaskan atribut-atribut kualitas dengan mudah, namun tidak bisa menjabarkan suatu atribut tergolong kebutuhan basic atau attractive sebagaimana Kano.

Dengan menggunakan teori fuzzy, analisis KANO bisa lebih kuantitatif dalam mengevaluasi keputusan yang bersifat subyektif. Hal yang sama terkait fuzzy menurut Ciptomulyono (1996), teori fuzzy menawarkan konsep dalam suatu frame work untuk menampung adanya informasi yang tidak pasti maupun samar (imprecise).

\footnotetext{
*) Dosen Teknik Industri

Universitas PGRI Adi Buana Surabaya
} 
Penggunaan terori fuzzyset memberi flesibilitas untuk menampung ketidakpastian akibat samarnya informasi yang dimiliki maupun unsure preferensi yang subyektif yang dapat digunakan dalam pengambilan keputusan.

Penggunaan fuzzy-Kano sudah digunakan untuk metode QFD (Quality Function Development) di industri manufaktur seperti yang yang sudah dikembangkan oleh Lee at al (2007). Dimana hasil dari penggabungan fuzzy-KANO mampu memperbaiki hasil output dari QFD. Tetapi hal ini belum digunakan di bidang industri jasa yang mempunyai karakteristik berbeda jika dibandingkan dengan industri manufaktur. Hal ini yang merupakan gap penelitian yang akan diteliti dalam riset ini.

Dalam penelitian ini akan menggunakan metode Fuzzy KANO-QFD untuk pengukuran performansilayanan kendaraan umum. Model Kano digunakan untuk mencari tingkat kepuasan pengguna kendaraan umum dan memetakannya, dalam model ini Kano mencari kepuasan pengguna dengan requirement produk dengan beberapa kategori: Must Be Requirements, One Dimensional Requirements, Attractive requirements. Menurut Ciptomulyono (1996), teori fuzzy menawarkan konsep dalam suatu frame work untuk menampung adanya informasi yang tidak pasti maupun samar (imprecise). QFD adalah metode perencanaan yang terstruktur untuk menentukan keinginan dan kebutuhan konsumen dan melakukan evaluasi secara sistematis untuk memuaskan konsumen. Untuk memberikan ilustrasi implementasi model yang dikembangkan ini dalam industri jasa, maka akan diujicoba untuk permasalahan transportasi kendaran umum.

Tujuan yang ingin dicapai dalam penelitian ini yaitu :

1. Menghasilkan model pengukuran kualitas layanan terhadap industri jasa layanan transportasi umum.

2. Merancang sistem layanan kendaraan umum berdasarkan metode Fuzzy-Kano QFD.

Melalui penelitian ini diharapkan dapat memberikan kontribusi kepada berbagai pihak dalam upaya menangani dan mengatasi kasus-kasus yang sering terjadi pada kendaraan umum,yaitu :

1. Model yang dikembangkan bisa membantu penyelenggara layanan kendaraan umum dalam upaya mengantisipasi dan menangani ketidaknyamanan terhadap layanannya.

2. Bagi pemerintah daerah dan DLLAJR, dapat dijadikan acuan dalam upaya mengantisipasi dan menangani ketidaknyamanan dalam pelayanan kendaraan umum.

\section{KAJIAN PUSTAKA}

Model Kano digunakan untuk mencari tingkat kepuasan pengguna. Di dalam model ini, Kano mencari kepuasan pengguna dengan requirement produk dengan beberapa kategori:

- Must Be Requirements : Jika kriteria ini tidak bisa dipenuhi, maka kriteria ini tidak akan mampu meningkatkan kepuasan pengguna, sebaliknya jika kriteria ini terpenuhi maka akan dapat meningkatkan kepuasan pengguna. Must be ini menjadi kriteria dasar dari produk.

- One Dimensional Requirements: dengan memenuhi kriteria ini, maka kepuasan pengguna akan menjadi lebih proposional, semakin tinggi tingkat pemenuhan requirement ini maka semakin tinggi tingkat kepuasan pengguna dan sebaliknya. Kriteria ini menjadi kriteria yang sebenarnya diinginkan oleh pengguna.

Attractive requirements: kriteria ini adalah kriteria produk dimana yang memiliki pengaruh terbesar bagaimana sebuah atribut bisa meningkatkan kepuasan pengguna, saat atribut ini diberikan pada produk. Kriteria ini menjadi yang diharapkan oleh pengguna, namun jika kriteria ini tidak mampu dipenuhi maka tidak ada kekecewaan dari pengguna. 


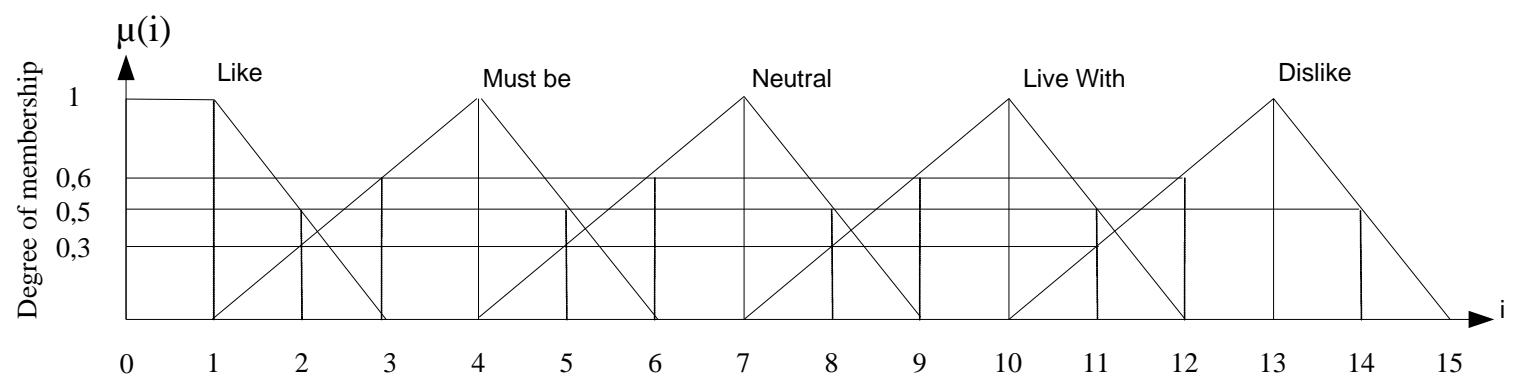

Gambar 1. Skala Linguistik Fuzzy-KANO

Dengan menerapkan fungsi keanggotaan fuzzy sebagaimana terlihat pada gambar 1 , diharapkan keberadaan kriteria-kriteria yang memiliki jumlah indikator pada kategori yang bersebelahan juga dapat memberikan pengaruh pada penyusunan indek. Formulasinya adalah sebagai berikut :

$$
\begin{aligned}
& R A_{w, i}=\sum K_{w, i} \\
& R R_{w, i}=\sum K_{w, i} / P_{w}
\end{aligned}
$$

Dimana :

$\mathrm{RA}_{\mathrm{w}, \mathrm{i}}=$ index rangking absolut dengan kategori i pada kriteria $\mathrm{w}$

$\mathrm{RR}_{\mathrm{w}, \mathrm{i}}=$ index rangking relatif dengan kategori i pada kriteria $\mathrm{w}$

$\mathrm{K}_{\mathrm{w}, \mathrm{i}}=$ hasil fungsi keanggotaan kategori i pada tiap skala wilayah $\mathrm{w}$

\begin{tabular}{|c|c|c|c|c|c|c|c|c|c|c|c|c|c|c|c|}
\hline & \multicolumn{3}{|c|}{ Like } & \multicolumn{3}{|c|}{ Must be } & \multicolumn{3}{|c|}{ Neutral } & \multicolumn{3}{|c|}{ Live With } & \multicolumn{3}{|c|}{ Dislike } \\
\hline & $\mathrm{H}$ & & $\mathrm{L}$ & $\mathrm{H}$ & $M$ & $\mathrm{~L}$ & $\mathrm{H}$ & M & $\mathrm{L}$ & $\mathrm{H}$ & $M$ & $\mathrm{~L}$ & $\mathrm{H}$ & $M$ & $\mathrm{~L}$ \\
\hline $\begin{array}{l}\text { Functional } \\
\text { Questionnaire }\end{array}$ & 1 & 0,8 & 0,6 & 1 & $0, \varepsilon$ & 0,6 & 1 & 0,8 & 0,6 & 1 & 0,8 & 0,6 & 1 & 0,8 & 0,6 \\
\hline $\begin{array}{l}\text { Dysfunctional } \\
\text { Questionnaire }\end{array}$ & 1 & 0,8 & 0,6 & 1 & 0, & 0,6 & 1 & 0,8 & 0,6 & 1 & 0,8 & 0,6 & 1 & 0,8 & 0,6 \\
\hline
\end{tabular}

Tabel 1. Fungsi Keanggotaan Kuesioner Model Fuzzy KANO

\section{METODE PENELITIAN}

\section{Pengumpulan dan Pengolahan Data}

Proses pengumpulan data ini dilakukan dengan menggunakan:

a. Kuisioner.

Kuisioner disebarkan kepada pengguna yang sudah menggunakan jasa layanan kendaraan umum, disebar dengan variasi usia, latar belakang pendidikan, jenis kelamin dan pekerjaan yang berbeda. Kuisioner ini dirancang dengan menggunakan standar kuisioner model Kano yaitu mencari pemetaan jawaban like, must be, neutral, like with, dislike.

b. Observasi.

Observasi pengamatan terhadap pelayanan penumpang bis kota di Surabaya.

\section{Penentuan populasi dan pengambilan sampel}

Sebagai populasi dalam penelitian ini adalah penumpang di bis kota di wilayah Surabaya, utamanya untuk jalur dari terminal Bungurasih-Perak, dan sebaliknya. Untuk menentukan jumlah sample penelitian, maka digunakan perhitungan Bernoulli. Ukuran sample minimum dalam penelitian ini dapat dihitung sebagai berikut :

$$
N \geq \frac{\mathrm{Z}^{\alpha} / 2^{2} \times \mathrm{p} \times \mathrm{q}}{\mathrm{e}^{2}}
$$

Dimana :

$\mathrm{N}=$ jumlah responden minimal yang dapat diambil.

$Z \alpha / 2$ = tingkat level kepercayaan yang akan digunakan (95\%).

$\mathrm{P}=$ proporsi jumlah responden yang mengisi dengan benar pada kuesioner pendahuluan. 
$q=$ proporsi jumlah responden yang mengisi dengan salah pada kuesioner pendahuluan.

e = tingkat error yang diijinkan.

$\alpha=$ taraf signifikasi.

Hasil penyebaran kuesioner dalam penelitian ini bahwa 50 kuesioner yang disebarkan terdapat 1 buah kuesioner yang dianggap salah, karena responden tidak memberikan jawabannya pada beberapa pertanyaan. Dengan menggunakan tingkat kepercayaan sebesar $95 \%$ dan tingkat kesalahan sebesar $5 \%$, maka kecukupan data untuk penelitian ini yaitu :

$$
N \geq \frac{1.96^{2} \times 0.98 \times 0.02}{0.05^{2}}=30
$$

Untuk itu kuesioner yang disebarkan sebesar 30 buah.

\section{Variabel Penelitian}

Atribut Voice of Customemerujuk hasil penelitian terdahulu terhadap bus Trans Jakarta oleh Murdiono (2006). Atribut-atribut tersebut adalah :

a. Dimensi Assurance (Jaminan):
a. Keamanan
b. Ongkos/Tarip

b. Dimensi Tangibles (Produk-produk fisik):
a. Tempat duduk
b. Kebersihan
c. Udara bersih
d. Fasilitas halte
e. Fasilitas terminal
f. Fasilitas toilet

c. Dimensi Reliability (Kehandalan) : Ketepatan waktu

d. Dimensi Responsiveness(Daya tanggap) :
a. Perilaku sopir
b.Perilaku kondektur

\section{HASIL DAN PEMBAHASAN}

\section{Analisis Kebutuhan Konsumen dengan Model Fuzzy-Kano}

Dari perhitungan Fuzzy KANO, diperoleh pemetaan kategori masing-masing atribut seperti dalam tabel 2.

Tabel 2. Penilaian Fuzzy Kano untuk bis penumpang umum

\begin{tabular}{|l|c|l|l|l|l|l|c|c|}
\hline $\begin{array}{l}\text { CUSTOMER } \\
\text { REQUIREMENT }\end{array}$ & $\mathbf{A}$ & $\mathbf{O}$ & $\mathbf{M}$ & $\mathbf{I}$ & $\mathbf{R}$ & $\mathbf{Q}$ & JUMLAH & $\begin{array}{l}\text { FUZZY-KANO } \\
\text { CATEGORY }\end{array}$ \\
\hline Keamanan & 12 & 1 & 0 & 12 & 3 & 2 & 30 & $\mathrm{~A}$ \\
Ongkos/Tarip & 9 & 1 & 0 & 19 & 1 & 0 & 30 & $\mathrm{~A}$ \\
Tempat Duduk & 5 & 1 & 0 & 18 & 3 & 3 & 30 & $\mathrm{~A}$ \\
Kebersihan & 1 & 3 & 5 & 15 & 5 & 1 & 30 & $\mathrm{M}$ \\
Udara Bersih & 3 & 1 & 0 & 17 & 6 & 3 & 30 & $\mathrm{~A}$ \\
Fasilitas Halte & 1 & 0 & 0 & 24 & 4 & 1 & 30 & $\mathrm{I}$ \\
Fasilitas Terminal & 0 & 0 & 1 & 27 & 2 & 0 & 30 & $\mathrm{I}$ \\
Fasilitas Toilet & 0 & 0 & 0 & 21 & 8 & 1 & 30 & $\mathrm{I}$ \\
Ketepatan Waktu & 2 & 1 & 5 & 20 & 1 & 1 & 30 & $\mathrm{I}$ \\
Perilaku Sopir & 3 & 1 & 5 & 19 & 1 & 1 & 30 & $\mathrm{I}$ \\
Perilaku & 2 & 2 & 3 & 20 & 2 & 1 & 30 & \\
Kondektur & & & &
\end{tabular}

\section{Analisa House Of Quality}

a. Analisis tingkat kepentingan (What)

Tingkat kepentingan atribut yang dipentingkan oleh pelanggan dapat dilihat pada tabel 3 . 
Tabel 3. Nilai rata-rata tingkat kepentingan atribut bis penumpang umum

\begin{tabular}{|l|c|c|}
\hline CUSTOMER REQUIREMENT & SKALA KEPENTINGAN & URUTAN KEPENTINGAN \\
\hline Keamanan & 4,65 & 3 \\
Ongkos/Tarip & 4,55 & 4 \\
Tempat Duduk & 4,75 & 1 \\
Kebersihan & 4,32 & 6 \\
Udara Bersih & 4,66 & 2 \\
Fasilitas Halte & 3,01 & 11 \\
Fasilitas Terminal & 3,44 & 7 \\
Fasilitas Toilet & 3,28 & 10 \\
Ketepatan Waktu & 4,44 & 5 \\
Perilaku Sopir & 3,32 & 9 \\
Perilaku Kondektur & 3,34 & 8 \\
\hline
\end{tabular}

\section{b. Analisis Improvement Rate}

Improvement rate atau rasio perbaikan merupakan suatu ukuran seberapa besar usaha yang dilakukan untuk meningkatkan kualitas.

Tabel 4. Improvement Ratio untuk setiap atribut bis penumpang umum

\begin{tabular}{|l|l|c|c|}
\hline No & Atribut & Target Value & Improvement Rate \\
\hline 1 & Keamanan & 4,95 & 1,05 \\
2 & Ongkos/Tarip & 4,95 & 1,06 \\
3 & Tempat Duduk & 4,87 & 1,04 \\
4 & Kebersihan & 4,78 & 1,00 \\
5 & Udara Bersih (AC) & 4,85 & 1,02 \\
6 & Fasilitas Halte & 3,87 & 1,00 \\
7 & Fasilitas Terminal & 3,76 & 1,00 \\
8 & Fasilitas Toilet & 3,77 & 1,00 \\
9 & Ketepatan Waktu & 4,00 & 1,00 \\
10 & Perilaku Sopir & 4,34 & 1,06 \\
11 & Perilaku Kondektur & 4,25 & 1,03 \\
\hline
\end{tabular}

c. Analisis Relative Importance Index

Dimana :

$$
\text { Relative Importance Index }=(1+m)^{k} x \mathbf{I R}_{0}
$$

$m=\max (|\mathrm{SI}|,|\mathrm{D}| \mid) ; \mathrm{R}_{0}=$ traditional improvement ratio $;{ }^{\mathrm{k}}=$ Fuzzy Kano Category $(\mathrm{I}=0$;

$\mathrm{M}=0,5 ; \mathrm{O}=1 ; \mathrm{A}=2)$

Adapun prioritas atribut-atribut layanan yang diharapkan konsumen seperti ditunjukkan pada tabel 5.

Tabel 5. Relative Importance Index bis penumpang umum

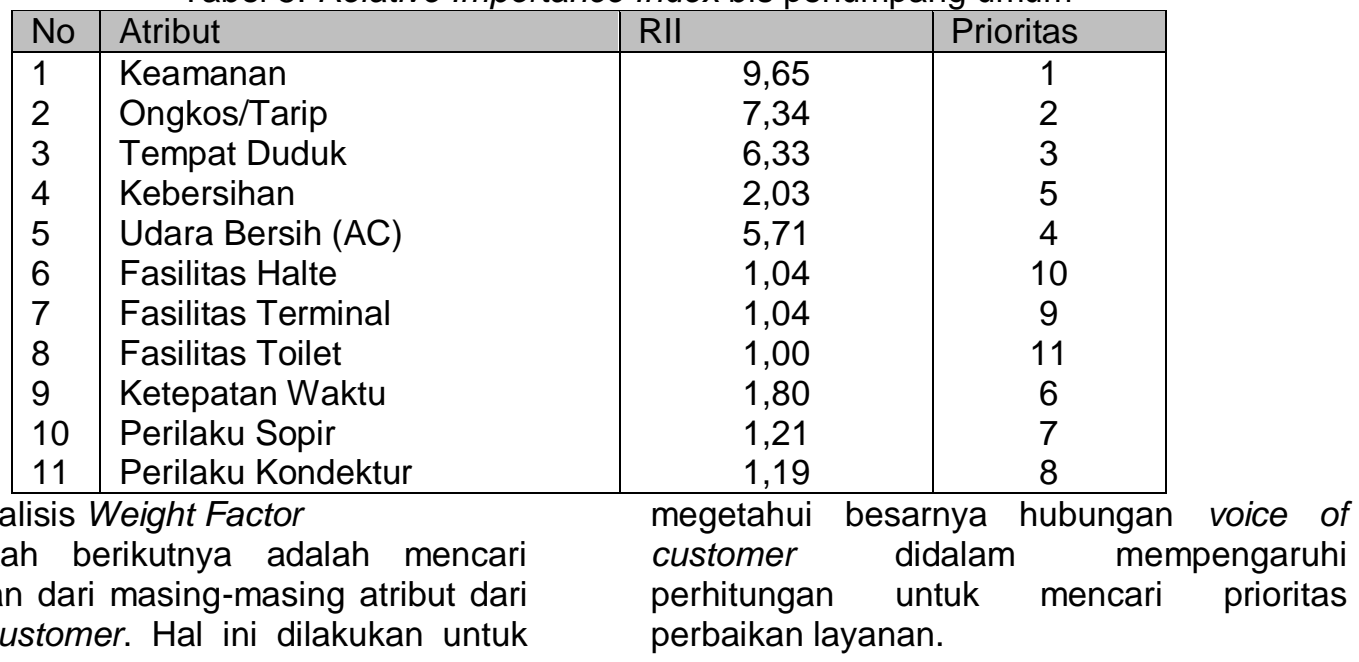


Tabel 6. Weight Factor bis penumpang umum

\begin{tabular}{|l|l|c|c|}
\hline No & Atribut & Weight & Prosentase \\
\hline 1 & Keamanan & 10,07 & 25,14 \\
2 & Ongkos/Tarip & 7,50 & 18,72 \\
3 & Tempat Duduk & 6,49 & 16,20 \\
4 & Kebersihan & 2,09 & 5,21 \\
5 & Udara Bersih (AC) & 5,94 & 14,83 \\
6 & Fasilitas Halte & 1,04 & 2,60 \\
7 & Fasilitas Terminal & 1,04 & 2,60 \\
8 & Fasilitas Toilet & 1,00 & 2,50 \\
9 & Ketepatan Waktu & 1,80 & 4,49 \\
10 & Perilaku Sopir & 1,54 & 3,85 \\
11 & Perilaku Kondektur & 1,55 & 3,87 \\
\hline
\end{tabular}

e. Analisis Respon Teknis

Untuk memenuhi kebutuhan layanan pengguna bis yang didapat dari hasil kuisioner, maka timbullah respon teknis yang dicari untuk menjawab kebutuhan tersebut, agar bisa lebih meningkatkan kepuasan pengguna bis. Respon teknis dengan nilai kontribusi paling besar adalah respon teknis yang diprioritaskan untuk dilaksanakan.
Layanan transportasi bis untuk penumpang umum berdasarkan perhitungan dari house of quality mengutamakan/memprioritaskan ketersediaan tempat duduk, petugas keamanan, tempat informasi dan pengaduan penumpang.

Tabel 7. Prioritas repon teknis bis penumpang umum

\begin{tabular}{|c|l|c|c|c|}
\hline No & Atribut & Score & Prosentase & Prioritas \\
\hline 2 & Kecukupan waktu naik/turun bis & 145 & 3,37 & 13 \\
3 & Petugas keamanan & 332 & 7,73 & 2 \\
4 & Kondisi bis (interior dan eksterior) & 322 & 7,48 & 4 \\
5 & Karcis balam bis & 230 & 5,35 & 9 \\
6 & Kepastiangganan tariff & 60 & 1,40 & 20 \\
7 & Kelebihan ongkos & 203 & 4,73 & 10 \\
8 & penggolongan tarip & 12 & 0,27 & 26 \\
9 & Ketersediaan tempat duduk & 165 & 3,84 & 12 \\
10 & Tersediannya Tempat sampah & 415 & 9,64 & 1 \\
11 & Tersediannya AC & 108 & 2,52 & 16 \\
12 & Pengharum ruangan & 305 & 7,07 & 5 \\
13 & Bebas pedagang asongan, pengemis, pengamen, & 136 & 3,16 & 14 \\
14 & asap rokok & 186 & 4,33 & 11 \\
15 & Dekat ji Halte dan Terminatan penyebrangan & 51 & 1,19 & 22 \\
16 & Informasi dan pengaduan & 47 & 1,09 & 23 \\
17 & jumlah toilet lebih dari 3 kamar & 330 & 7,66 & 3 \\
18 & ketersediaan air dan tisu & 55 & 1,27 & 21 \\
19 & Jalur Khusus & 69 & 1,61 & 19 \\
20 & Kecukupan Armada Bis & 240 & 5,57 & 8 \\
21 & Disiplin waktu & 40 & 0,94 & 24 \\
22 & Tidak ugal-ugalan & 110 & 2,56 & 15 \\
23 & Ramah dan sopan & 261 & 6,07 & 7 \\
24 & Komunikative & 69 & 1,62 & 18 \\
25 & Berseragam & 39 & 0,90 & 25 \\
26 & Informative & 296 & 6,88 & 6 \\
\hline
\end{tabular}




\section{KESIMPULAN}

Kesimpulan yang dapat diambil dari pengolahan dan analisa yang telah dilakukan didapat 11 (sebelas) kriteria kebutuhan layanan VoC (Voice of Customer) dan 26 (dua puluh enam) atribut respon teknis yang digunakan untuk mendesain sistem layanan.
Perhitungan untuk VoC untuk bis penumpang umum, nilai tertinggi pada atribut ketersediaan tempat duduk dengan skor 9,64. Untuk itu, hal yang bisa diusahakan yaitu dengan menambahkan armada bus dan juga bisa menjadwalkan rute yang lebih banyak. Selain hal diatas, perlu adanya petugas keamanan serta informasi dan pengaduan konsumen, yang skornya 7,73 dan 7,66.

\section{DAFTAR PUSTAKA}

Ciptomulyono, U. (1996),"Model Fuzzy Goal Programming Untuk Perencanaan Produksi Terpadu", IPTEK, Vol. November, Hal: 116-127.

Cohen, Lou (1995), Quality Function Deployment, How To Make QFD Work For You, AddisonWesley Publishing Company, Mass.

Hanoum, Syarifa, Singgih, M.L., dan Noufal Faiz (2009),"Prioritizing Healhcare Service Attributes: Comparing Importance Performance Analysis and KANO's Model", Asia Pacific Conference on Manufacturing System, Yogyakarta 4-5 Nopember 2009.

Kano, N., Seraku, K., Takahashi, F., dan Tsuji, S. (1984). "Attractive Quality And Must-Be Quality", The Journal of the Japanese Society for Quality Control, Vol.14(2), Pages 39-48.

Lee,Y., Sheu,L., dan Tsou,Y. (2007). "Quality Function Deployment Implementation Based On Fuzzy Kano Model : An Application In PLM System", Computers \& Industrial Engineering, Doi:10.1016/j.cie.2007.11.014

Murdiono, Jatmiko (2006). "Persepsi Konsumen Terhadap Pelayanan "Busway“ Trans Jakarta", Jurnal Ekubank, Vol. 3, Pages 12-17.

Prihono, (2011)."Disain Layanan Kendaraan Umum untuk Wanita Berbasis Fuzzy-Kano Quality Function Development (QFD)", Jurnal Teknik dan Manajemen Industri, Vol.7, Hal. 44-54.

Ramaswamy Rohit (1996). Design And Management Of Service Processes" Keeping Customer For Life", Addison-Wesley Publishing Company, Inc.

Sauerwein, E., Bailom, F., Matzler, K., Hinterhuber, H. (1996), The Kano Model : How To Delight Your Customers, Proceeding of International Working Seminar on Production Economics, Pages. 313-327.

Temponi C.,Yen J. dan Tiao W.A. (1999). "House of Quality: A fuzzy Logic-Based Requirement Analysis", European Journal of Operational Research 117, 340-354.

Usman, Husaini dan Akbar, Purnomo Setiady (2006), Pengantar Statistik, PT. Bumi Aksara, Jakarta.

Zadeh, L.A. (1965). Fuzzy sets. Information and Control,Vol.8, Pages 338-353. 